\title{
Spatial and seasonal variations in stem respiration of beech trees (Fagus sylvatica)
}

\author{
Éric Ceschia ${ }^{a^{*}}$, Claire Damesin ${ }^{\mathrm{a}}$, Stéphanie Lebaube ${ }^{\mathrm{b}}$, Jean-Yves Pontailler $^{\mathrm{a}}$ and Éric Dufrêne ${ }^{\mathrm{a}}$ \\ ${ }^{a}$ Université Paris XI, Laboratoire d'écophysiologie végétale, Bât. 362, 91405 Orsay, France \\ ${ }^{\mathrm{b}}$ UMR INRA UHP, Écologie et Écophysiologie forestières, 54280 Champenoux, France
}

(Received 18 April 2002; accepted 19 June 2002)

\begin{abstract}
Stem respiration of adult beech (Fagus sylvatica L.) trees was measured in the field in eastern France at several levels in the crown and along the stem. Strong variations in respiration rates throughout the season and within the trees were mainly caused by gradients in stem temperature, growth rates and distribution of living cells. The higher respiration rates, were measured in the upper crown. During the non-growing season, maintenance respiration ranged between 7.2 and $528 \mu \mathrm{mol} \mathrm{m}^{-3} \mathrm{~s}^{-1}$ at breast height and in the upper crown, respectively. $Q_{10}$ increased along the stem from 1.3 at breast height to 2.0 in the upper crown. There was a linear relationship between [N] and the percentage of living cells in the wood, but respiration increased strongly with [N]. Growth respiration accounted for $45-76 \%$ of annual stem respiration, and the growth

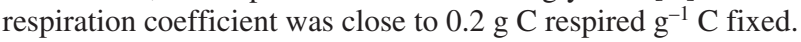

beech / stem and branch respiration / living cell / nitrogen concentration

Résumé - Variations spatiales et saisonnières de la respiration ligneuse chez le Hêtre (Fagus sylvatica). La respiration ligneuse a été mesurée de façon continue sur des Hêtres (Fagus sylvatica L.) adultes dans une forêt de l'est de la France, à trois niveaux dans la couronne de branches en 1997 et à deux voire trois niveaux le long du tronc en 1998. Les fortes variations du taux de respiration observées au cours de la saison et au sein de l'arbre étaient essentiellement causées par des gradients de température, de taux de croissance et de distribution des cellules vivantes. Les plus fortes valeurs de respiration correspondaient au sommet de la couronne. Pendant la période de non-croissance, la respiration d'entretien variait entre 7,2 et $528 \mu \mathrm{mol} \mathrm{m}{ }^{-3} \mathrm{~s}^{-1}$ à $1,3 \mathrm{~m}$ et au sommet de la couronne, respectivement. Le $Q_{10}$ augmentait aussi le long du tronc de 1,3 à 2,0 pour ces mêmes positions. Il existait une relation linéaire entre la concentration en azote, [N], dans le bois et le pourcentage de cellules vivantes. La respiration d'entretien augmentait fortement avec [N]. La respiration de croissance représentait 45 à $76 \%$ de la respiration annuelle des troncs, et le coût de synthèse du bois était de $0,2 \mathrm{~g} \mathrm{C}$ respiré $\mathrm{g}^{-1} \mathrm{C}$ fixé dans le tissu.

hêtre / respiration ligneuse / cellule vivante / concentration en azote

\section{INTRODUCTION}

Interest in the carbon balance of forests has increased in recent decades. Autotrophic respiration is a major component in the annual carbon balance of forest ecosystems, and can consume up to $60 \%$ of gross carbon assimilation [38]. Woody-tissue respiration alone annually consumes ca. $11-33 \%$ of total net daytime carbon assimilation [37]. Moreover, since forest ecosystems are very finely balanced be- tween being a carbon source or a carbon sink [26], it has become crucial to improve the accuracy of models used for estimating forest carbon budgets, and thus to improve our knowledge of stem respiration processes.

Although the biochemical pathways are similar, wood respiration is generally separated into two components e.g. [2, 41]: growth respiration, which provides the energy needed to synthesise new tissues, is a function of wood growth; and maintenance respiration, which maintains existing living

* Correspondence and reprints

Tel.: +33 (0)4 736244 25; fax: +33 (0)4 736244 57; e-mail: eric.ceschia@clermont.inra.fr

Current address: INRA-Agronomy Unit, 234 Avenue du Brézet, 63039 Clermont-Ferrand, France 
cells, is usually a function of biomass [36], sapwood volume [19], surface area [46] or nitrogen content [28]. This separation in two components is necessary to understand how stand development, climate and management affect forest carbon cycling. A simple model can be used to calculate woody respiration separated into those two components on a short time scale or per annum $[2,42]$. Thus estimates of the growth respiration coefficient $\left(r_{\mathrm{G}}\right)$ and biomass increments, of standing biomass and maintenance respiration rate $\left(r_{\mathrm{M}}\right)$, are required to estimate stem respiration at stand level. Usually, $r_{\mathrm{G}}$ and $r_{\mathrm{M}}$ are derived from measurements at breast height $(1.3 \mathrm{~m})$, but some studies have shown that respiration varies with stem and branch diameter or height [4, 5, 8, 18, 32, 40, 41, 49], or with the woody organ (stem or branch) considered [5, 28, 32, 41, 49].

The factor by which maintenance respiration varied between different locations in the trees differed greatly among the different studies, and depended on the units in which respiration was calculated. An almost 30-fold difference in respiration rates along the stem on a wood mass base was reported in Yoda et al. [49] for different tree species, a 3- and 4.5-fold on a surface-area base and volume base in Ryan et al. [40] for Pinus radiata, and a 10- to 40-fold on a surface-area base for Abies amabilis in Sprugel [41].

There may be several causes for a spatial variation in total stem respiration:

(1) Differences in wood composition [3] and in the amount of wood produced along the stem will give differences in growth respiration.

(2) The distribution of living cells within the stem can affect maintenance respiration rates [45, 46].

(3) The transport and storage of carbohydrates in the stem and in the branches can cause variations in respiration rates as it was shown by Malkina et al. [29] and Lavigne [18].

(4) Sapflow could transport part of the $\mathrm{CO}_{2}$ respired by the stem [12, 23, 30,33] and it could release it in the upper parts of the stem. However, Edwards and Wullschleger [11] and Ceschia [7] found little evidence of the effect of the sapflow on stem respiration.

(5) Temperature is also an important factor that influences the spatial variation of stem respiration. Stem temperature is usually higher in the upper parts of the canopy, since the stem is more exposed to sunlight and the temperature amplitude is greater. Because of the smaller diameter of the organs, the stem tissues also warm faster at the top than at the base of the stem. Indeed, $Q_{10}$, the factor expressing respiration increase for a temperature increase of $10{ }^{\circ} \mathrm{C}$, can vary with height along the stem [8] or with the organ in question, stem or branch [28].

Very few models dealing with carbon budgets for an entire ecosystem, take into account spatial variations in stem respiration and few attempts have been made to test the impact of such variations on calculations of net carbon uptake at stand level [45]. More information is also needed to be able to choose the best unit to scale up stem or branch respiration to stand level, because this unit can have a large impact on the final results. Hitherto, the most common units have been surface area $[18,46]$ or sapwood volume [36], but sapwood fresh mass [49] or sapwood dry mass and nitrogen content [28, 37-40] have also been used to express maintenance respiration. Sprugel et al. [43] suggested that sapwood volume was a better calculation base, because respiration rates per unit volume are rather constant within coniferous species. Knowledge of the distribution of living cells in the stem would make it possible to choose the best unit (surface or volume) for expressing stem maintenance respiration, and it would minimize errors when scaling up local measurements to stand level [45].

Even if within-tree variability in respiration is large, it should be borne in mind that between-tree variability can be still larger, especially on a multi-aged forest. Indeed, temperature-corrected respiration, calculated on a surface-area base, was found to vary among trees by a factor 10 to 40 [41]. In Carey et al. [6], maintenance respiration, calculated on a sapwood volume base, decreased with diameter at breast height (DBH) and age; it was attributed to a decrease in the number of living cells or to diffusion problems in older trees.

In the present paper, we measured stem respiration of a temperate deciduous species, Fagus sylvatica L. Measurements were performed almost continuously at three levels in the crown of one tree during the growing season of 1997. In 1998, measurements were performed continuously at two different positions along the stem on four dominant or co-dominant trees during the growing season and at a third level after the growing season. The aims were (1) to quantify the variability of different parameters (percentage of living cells and nitrogen concentration in the wood, stem temperature and growth) and their influence on stem respiration throughout the year, between trees and within trees; (2) to determine the relative importance of maintenance and growth respiration on an annual base and (3) to calculate the growth respiration coefficient.

\section{MATERIALS AND METHODS}

\subsection{Site description}

The study site is situated in the State forest of Hesse, eastern France $\left(48^{\circ} 40^{\prime} \mathrm{N}, 7^{\circ} 04^{\prime} \mathrm{E}\right.$, elevation $305 \mathrm{~m}$, area 0.63 ha, slope $<2 \%$ ), and is one site within the Euroflux project (FR02). Mean annual precipitation and air temperature are $820 \mathrm{~mm}$ and $9.7^{\circ} \mathrm{C}$, respectively. The soil is a gleyic luvisol, according to the F.A.O. classification. Beech (Fagus sylvatica L.) is the dominant tree species and other species are Betula pendula Roth, Carpinus betulus L., Fraxinus excelsior L., Larix decidua Mill., Prunus avium L. and Quercus petraea (Matt.) Liebl. In 1997, most of the trees were 25 to 35 -year-old and stand density was 4000 trees $\mathrm{ha}^{-1}$, with a mean height of $13 \mathrm{~m}$ in 1997 and a diameter at breast height (DBH) of $72 \mathrm{~mm}$. Leaf area index (LAI) was 5.6 in 1997 [14] and all beeches showed leaf emergence at the end of April. 


\subsection{Experimental set-up}

Stem respiration measurements in Hesse started on one tree in 1997 (from May to December) and were extended to four trees in 1998 (from April to October). In the first year, three cuvettes were installed on the main stem at a high level in the crown of a beech tree. Its height and DBH were $15.5 \mathrm{~m}$ and $100 \mathrm{~mm}$, respectively. Permanent cuvettes, made of two halves of a glass cylinder, were installed on the stem at 0.25 (upper crown), 1.5 (mid-crown) and 2.5 (low crown) $\mathrm{m}$ from the top of the tree. These positions corresponded to stem diameters of $2.5,12.9$ and $23.6 \mathrm{~mm}$ at the beginning of the season. The length of the cuvettes ranged from 2.1 (upper crown) to $4.5 \mathrm{~cm}$ (mid-crown and low crown).

In 1998, four dominant or co-dominant trees were selected among beech trees that were already equipped with sapflow sensors and band-dendrometers. Two cuvettes were installed on each tree: one at breast height (diameter ranged from 108 to $143 \mathrm{~mm}$ ) and one at mid-stem (diameter ranged from 52 to $70 \mathrm{~mm}$ ). This position usually corresponded to the base of the crown. The cuvettes were $22 \mathrm{~cm}$ long, made of two half-cylinders of transparent Acrylic resin and a fan was used to mix the air inside the chambers.

In 1998, after growth had ceased (day of year (DOY) 245, see below), stem respiration was also measured at $0.8 \mathrm{~m}$ from the top of the trees (upper stem) on which measurements were made at breast height and at mid-stem, but using the same glass cuvettes $(4.5 \mathrm{~cm}$ long) as were used in the crown in 1997. The diameter of the organs ranged from 5.3 to $16.8 \mathrm{~mm}$.

The cuvettes were sealed to the stem with large PVC soft foam and putty (Térostat-7, Téroson, Germany) that would allow the stem to grow. Stem respiration measurements were performed automatically using an infrared gas analyser (LI-6262, Li-COR, NE, U.S.A.) operating as an open system. $\mathrm{CO}_{2}$ evolution in all cuvettes was measured in sequence every 90 minutes. The cuvettes were covered with aluminium foil to avoid $\mathrm{CO}_{2}$ refixation by the bark. Airflow passing continuously through the cuvettes was adjusted to prevent a $\mathrm{CO}_{2}$ increase of more than $50 \mu \mathrm{mol} \mathrm{mol}{ }^{-1}$ inside the cuvettes. Airflow (ranging between 0.05 and $2 \mathrm{~L} \mathrm{~min}^{-1}$ ) was measured with mass-flow meters (AMW-43600V and AMW-3300, Honeywell, IL, U.S.A.) before and after the cuvettes to check their air-tightness. The air passing through the various cuvettes was selected using solenoid valves controlled by a data logger (CR10X, Campbell Scientific, Logan, U.S.A.), and directed through the analyser.

All data from the IRGA and the mass flow meters were recorded and stored every minute by a data logger. Temperature measurements were averaged and stored every 30 minutes by the CR10X in 1997 and by a Deltalogger (Delta-T devices, Cambridge, U.K.) in 1998. The automatic gas-exchange system was installed between April and November 1998. Technical problems prevented the use of data between September and October 1998, for one cuvette installed at breast height outside the growing season and for one of the cuvettes installed at mid-stem.

In 1997 , thermistors $\left(10 \mathrm{k} \Omega\right.$ at $25{ }^{\circ} \mathrm{C}$, Betatherm, Ireland) were used to measure air temperature in the cuvettes, assuming that stem temperature tracked air temperature very closely. In 1998, thermistors were inserted $2 \mathrm{~mm}$ under the bark to measure stem temperature in the cuvette. The thermistors were installed at three levels in the tree in 1998: at breast height, at mid-stem and where some extra cuvettes were installed on the upper stem on DOY 245.

\subsection{Diameter increment}

In 1998, the diameter increment below the breast height and mid-stem cuvettes was recorded hourly with an automatic band-dendrometer (Megatron MM30, Allinges, France). In the crown, the stem diameter increment was recorded monthly both years, as the mean of two measurements at $90^{\circ}$ to each other, made with a digital calliper (resolution $0.01 \mathrm{~mm}$ ), immediately above and below each cuvette. Calculations of respiration on a stem volume or surface-area base were corrected throughout the year for stem diameter increment.

\subsection{Data analysis}

Stem respiration measurements were fitted to the temperature variations for each cuvette, using the following equation:

$$
R=R_{15} Q_{10}^{((T-15) / 10)}
$$

where $R$ is stem respiration measured, $R_{15}$ is stem respiration estimated at $15^{\circ} \mathrm{C}, Q_{10}$ is the relative increase in $R$ for a temperature elevation of $10^{\circ} \mathrm{C}$ in air or wood temperature in the cuvette, and $T$ is air or wood temperature $\left({ }^{\circ} \mathrm{C}\right)$ in the cuvette.

Statistical analyses were conducted with version 6.12 of the Statistical Analysis System (SAS). A non-linear model procedure PROC NLIN was used to estimate the parameters $\left(R_{15}\right.$ and $\left.Q_{10}\right)$ of the exponential equation. For each cuvette, daily $R_{15}$ was averaged on three days (running mean) and $Q_{10}$ was calculated on a one-day, three-day and seven-day base.

\subsection{Estimation of the different components of stem respiration}

Two methods were used to estimate the contributions of growth and maintenance to the total respiration.

Method 1, or mature-tissue method [2]: this method assumes that maintenance respiration $\left(R_{\mathrm{M}}\right)$ at a reference temperature and for a given volume or surface area of wood, is constant throughout the year. The averaged maintenance respiration corrected for a temperature of $15^{\circ} \mathrm{C}\left(R_{\mathrm{M} 15}\right)$ was calculated for each cuvette from measurements made before and after the growing season. $R_{\mathrm{M}}$ was recalculated throughout the season using an averaged annual $Q_{10}$ for each cuvette and the seasonal temperature variations. $R_{\mathrm{M}}$ was then subtracted from total respiration $\left(R_{\mathrm{T}}\right)$ during the growing season for each cuvette and measurement occasion: the difference representing growth respiration $\left(R_{\mathrm{G}}\right)$ was summed for the whole year. The slope of the relationship between $R_{\mathrm{G}}$ integrated over the year, and total stem growth in the cuvettes, is the growth respiration coefficient $\left(r_{\mathrm{G}}\right)$.

Method 2, or periodic-growth method: $R_{\mathrm{G}}$ was estimated daily by subtracting estimated $R_{\mathrm{M}}$ (see above) for each cuvette from $R_{\mathrm{T}}$. A running mean over one week ( 3 days before and 3 days after the day of measurement) was then used to recalculate $R_{\mathrm{G}}$ and the stem growth rate in order to eliminate the diurnal variations in stem growth rate caused by water losses and recharge in the stem. The slope of the relationship between $R_{\mathrm{G}}$ and stem growth rate (corrected for time-lag to give the best fit) gave an estimate of $r_{\mathrm{G}}[1,42]$. Total respiration should not be used to calculate $r_{\mathrm{G}}$ since the part represented by maintenance respiration in $R_{\mathrm{T}}$ is changing with temperature throughout the season. This method provided a relationship between $\mathrm{C}$ fixed and $\mathrm{C}$ respired by growth respiration for each cuvette, while Method 1 gave a single relationship for all cuvettes.

For both methods, we used a wood density value of $636 \mathrm{~kg} \mathrm{~m}^{-3}$ [8], and we assumed that the carbon content of the woody tissues 
was $0.49 \mathrm{~g} \mathrm{C} / \mathrm{g}$ dry wood [31]. In June 1997, after a strong storm the upper and lower cuvettes installed in the crown slightly moved from their original location on the stem. Therefore, those two cuvettes were disregarded when calculating the growth respiration coefficient.

\subsection{Living cells and nitrogen content analysis}

Since we couldn't take samples on the trees used for respiration measurement in 1998, five trees having DBH similar to those used for respiration measurements were chosen outside the experimental site (less than $50 \mathrm{~m}$ from the measured trees). In September, after growth had ceased and before leaf fall, two increment cores were taken at breast height from the five trees. The first core was dried at $70{ }^{\circ} \mathrm{C}$ for $48 \mathrm{~h}$, and milled before nitrogen analysis by means of a Carlo Erba Elemental Analyser NA 1500 [17].

The length of the second core was equal to half the $\mathrm{DBH}$ of the stem. The sample was immediately frozen in dry ice and kept at $-80{ }^{\circ} \mathrm{C}$. The frozen increment cores were sectioned in the xylem at 3 to 8 depths between 1 and $60 \mathrm{~mm}$ under the cambium by means of a microtome. To ensure that at least one cell layer was intact, sections were $70 \mu \mathrm{m}$ thick. The sections were placed on a glass slide and stained with a Comassie blue solution for 3 minutes [44]. They were then rinsed, first with an identical solution, but without the stain, and finally with water [44]. The sections were mounted on slides in Canada balsam. The Comassie blue stained only the proteins of the cytoplasm and made it possible to determine which cells were living.

On the same date, several branches in the upper canopy were also sampled on the four trees for analysis of $[\mathrm{N}]$ and living cells. These branches were regarded as stems since for beech trees it is often difficult to distinguish the branches from the stem in this location and both are exposed to similar climatic conditions. The whole transverse-section of the branches was used for analysis of living cells. To estimate the amount of living cells in the periderm (including cambium, phloem, parenchyma and collenchyma) at breast height, the amount of living cells per volume of periderm for the branches was multiplied by the volume of the periderm at breast height. It was not possible to measure directly the amount of living cells in the periderm at breast height since the cells were damaged by the core sampler. The percentage area of live cells in each section was determined by means of a computer image-analysis system (Image Tool, University of Texas Health Science, San Antonio, TX, U.S.A.). To calculate the total surface area of living cells at breast height, the various sections in the xylem and the percentage of living cells in the periderm were integrated over the cross-sectional area of the stem.

\section{RESULTS}

\subsection{Stem growth}

Stem diameter increment in the crown started at the end of April in 1997 [22] and ceased approximately on 20 August (DOY 232). In 1998, growth started ca. DOY 130, and ceased at the end of August (ca. DOY 240), both in the middle and at the base of the stem (figure 1b). Growth, which was very well synchronised along the stem during this period, peaked for the first time in early June (DOY 157), decreased until DOY 167 (corresponding to a cool period), and peaked a second time on DOY 175. Thereafter, it slowly decreased until the end of August, even if minor peaks occurred on DOY 212

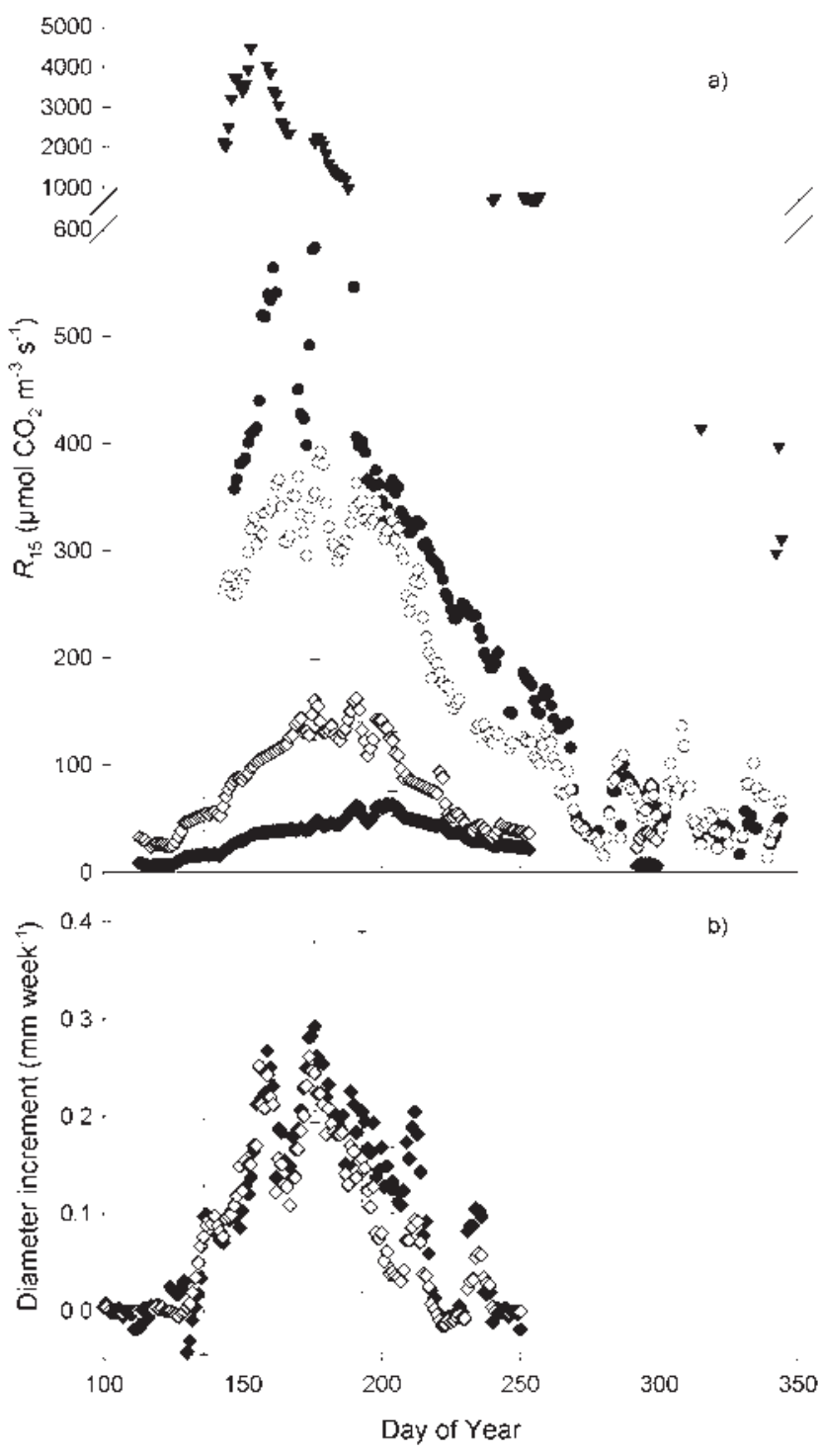

Figure 1. Seasonal and spatial variation in (a) stem respiration normalised to $15{ }^{\circ} \mathrm{C}\left(R_{15}\right)$ and calculated on a volume basis at breast height $(\diamond$, three to four cuvettes per point) and in the middle of the stem $(\diamond$, three cuvettes per point) in 1998 and at the base $(\bullet)$, middle (O) and top $(\boldsymbol{\nabla})$ of the crown in 1997 of dominant 25 -year-old beech trees at Hesse; (b) averaged stem diameter increment at breast height $(\diamond)$ and in the middle of the stem $(\diamond)$ in 1998 . The error bars represent the standard errors of the mean for the 1998 measurements and are presented for each of the four dates for which the standard errors were maximum for either the respiration rates or the diameter increments at breast height or in the middle of the stem. For further details, see text.

and 236. The diameter increment was on average $3.9 \mathrm{~mm}$ $(S E=0.4)$ at breast height, $4.9 \mathrm{~mm}(S E=0.6)$ in the mid-stem cuvettes and $4.4 \mathrm{~mm}(S E=0.6)$ in the upper stem cuvettes corresponding to annual relative diameter growth of 3.1,8.1 and $33.5 \%$, respectively. 


\subsection{Stem temperature}

Stem temperature at breast height and for the upper stem location ranged from -13 and $-12.8^{\circ} \mathrm{C}$, respectively, in November 1998, to 29.7 and $38.3^{\circ} \mathrm{C}$ in August 1998. The largest difference in temperature between the two levels was recorded in January, and reached $15.7^{\circ} \mathrm{C}$. On a diurnal and monthly average, temperature usually increased with height along the stem. On a monthly base, the difference in temperature between the cuvettes installed on the upper stem and at breast height was always positive (between $0.2{ }^{\circ} \mathrm{C}$ in March and $1.5^{\circ} \mathrm{C}$ in June), except in April, when the difference was close to $-0.2^{\circ} \mathrm{C}$.

\subsection{Stem respiration}

The peak of respiration, corrected for temperature, occurred in the middle of the growing season (figure la). In 1997, respiration increased first for the upper crown cuvette, but was rather well synchronised for the mid-crown and lower crown positions and growth respiration ceased for all cuvettes around DOY 270. In 1998, respiration increased suddenly on DOY 126, both at breast height and at mid-stem. This increase occurred four days before measurable growth started (figures $l a$ and $l b$ ). The peaks of respiration in the mid-stem cuvette occurred on DOY 176 and 191, while at breast height they occurred on DOY 191 and 204. Growth and respiration were not synchronised, and the peak of respi- ration at breast height occurred ca. 27 days after the first stem growth peak compared with only 18 days for the mid-stem cuvette.

Respiration estimated at $15{ }^{\circ} \mathrm{C}\left(R_{15}\right)$, calculated on a volume base, generally increased with height on the stem or decreased with increasing diameter. However, the lower crown cuvette installed in 1997 had a slightly higher respiration rate than the mid-crown cuvette on many occasions (figure la). The respiration rate in the upper crown cuvette was far higher than in the lower crown and mid-crown cuvettes throughout the season. In 1998 (figure 1a), the maximum values averaged for the breast height and mid-stem cuvettes were 65.4 $(S E=11.0)$ and $181 \mu \mathrm{mol} \mathrm{m}^{-3} \mathrm{~s}^{-1}(S E=33)$ respectively, whereas in 1997, the maximum value for the upper crown cuvette was above $4469 \mu \mathrm{mol} \mathrm{m}^{-3} \mathrm{~s}^{-1}$ (see table I). During the non-growing season, the trend of increase in respiration rates with increasing height or decreasing diameter remained, but the respiration rate at breast height, specifically, increased with increasing diameter (see figure $2 a$ and table I). The values of $R_{\mathrm{M} 15}$ before and after growth in 1998 were very similar, $7.0(S E=0.9)$ and $7.1(S E=1.6) \mu \mathrm{mol} \mathrm{m}^{-3} \mathrm{~s}^{-1}$, respectively, at breast height and $26.9(S E=3.0)$ and $32.6(S E=2.5) \mu \mathrm{mol}$ $\mathrm{m}^{-3} \mathrm{~s}^{-1}$ in the mid-stem cuvette. The variation in $R_{15}$ between trees in 1998 was relatively small compared with variation within trees. At breast height and at mid-stem, on a volume basis, the larger factors of variation during the season between trees were 2.4 and 3.6, respectively.

Table I. Spatial variation in stem respiration and $Q_{10}$ in the cuvettes during the season 1998 at breast height, mid-stem and for the upper stem of dominant beech trees and at three positions within the crown (low, mid-crown and upper crown) during the season of 1997 . The maximum annual values of stem respiration $\left(R_{15 \mathrm{MAX}}\right)$ and the averaged maintenance respiration before and after growth, normalized to $15^{\circ} \mathrm{C}\left(R_{\mathrm{M} 15}\right)$, were calculated on a volume $\left(\mu \mathrm{mol} \mathrm{m} \mathrm{m}^{-3} \mathrm{~s}^{-1}\right)$ or surface $\left(\mu \mathrm{mol} \mathrm{m} \mathrm{m}^{-2} \mathrm{~s}^{-1}\right)$ of stem base. Values in parenthesis are standard errors of the means.

\begin{tabular}{|c|c|c|c|c|c|c|c|c|}
\hline Cuvette positions & Year & $\begin{array}{l}\text { Diameter } \\
(\mathrm{mm})\end{array}$ & $\begin{array}{l}\text { Height } \\
(\mathrm{m})\end{array}$ & 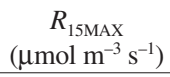 & $\begin{array}{c}R_{\mathrm{M} 15} \\
\left(\mu \mathrm{mol} \mathrm{m}^{-3} \mathrm{~s}^{-1}\right)\end{array}$ & $\begin{array}{c}R_{15 \mathrm{MAX}} \\
\left(\mu \mathrm{mol} \mathrm{m}^{-2} \mathrm{~s}^{-1}\right) \\
\end{array}$ & 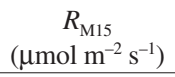 & $Q_{10}$ \\
\hline Breast height 1 & 1998 & 128 & 1.8 & 95.2 & $7.35(0.34)$ & 3.14 & $0.239(0.010)$ & $1.18(0.03)$ \\
\hline Breast height 2 & 1998 & 108 & 1.4 & 46.0 & - & 1.27 & - & $1.38(0.046)$ \\
\hline Breast height 3 & 1998 & 115 & 1.7 & 52.3 & $5.09(0.11)$ & 1.55 & $0.149(0.003)$ & $1.44(0.05)$ \\
\hline Breast height 4 & 1998 & 143 & 1.6 & 68.2 & $9.12(0.49)$ & 2.50 & $0.330(0.018)$ & $1.33(0.05)$ \\
\hline Mean Breast height & 1998 & $124(8)$ & $1.6(0.1)$ & $65.4(11.0)$ & $7.18(1.16)$ & $2.12(0.43)$ & $0.239(0.052)$ & $1.33(0.11)$ \\
\hline Mid-stem 2 & 1998 & 51.6 & 10.4 & 248 & $33.5(1.0)$ & 3.35 & $0.449(0.013)$ & $1.47(0.08)$ \\
\hline Mid-stem 3 & 1998 & 56.5 & 11.6 & 156 & $27.5(0.8)$ & 2.36 & $0.406(0.014)$ & $1.52(0.06)$ \\
\hline Mean Mid-stem & 1998 & $56.3(0.3)$ & $11.0(0.3)$ & $181(33)$ & $30.4(1.8)$ & $2.65(0.35)$ & $0.445(0.021)$ & $1.42(0.11)$ \\
\hline Upper stem 1 & 1998 & 13.6 & 15.0 & - & $547 *$ & - & $2.30 *$ & $1.99 *$ \\
\hline Upper stem 2 & 1998 & 15.4 & 13.2 & - & $147 *$ & - & $0.56^{*}$ & $2.11 *$ \\
\hline Low crown & 1997 & 23.6 & 13 & 583 & $48.0(3.2)$ & 3.67 & $0.287(0.019)$ & $1.79(0.03)$ \\
\hline Mid-crown & 1997 & 12.9 & 14 & 392 & $60.4(3.6)$ & 1.33 & $0.225(0.013)$ & $1.87(0.05)$ \\
\hline Upper crown & 1997 & 2.5 & 15.3 & 4469 & $528(56)$ & 2.32 & $0.441(0.039)$ & $1.85(0.07)$ \\
\hline
\end{tabular}

* Based on measurements made on DOY 245 only. 


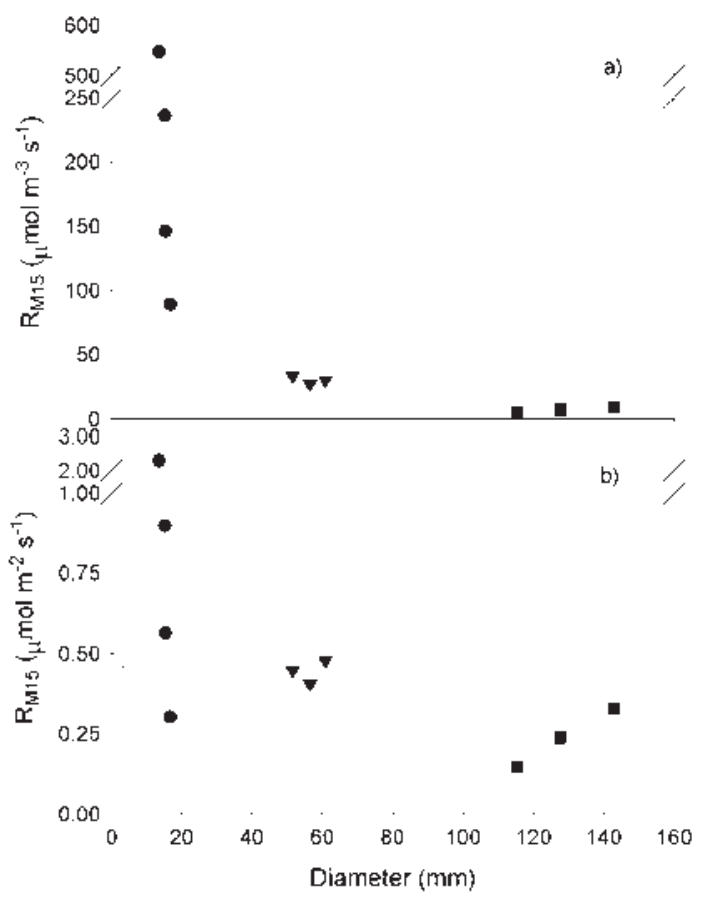

Figure 2. Spatial variation in annual mean of maintenance respiration estimated at $15^{\circ} \mathrm{C}\left(R_{\mathrm{M} 15}\right)$ calculated on a volume (a) or a surface-area base (b) as a function of stem diameter at Hesse in 1997 (O) and 1998 (O) at the top of the crown; in the middle of the stem $(\boldsymbol{\nabla})$ and at breast height (ם). One cuvette per point.

On a surface area base, the differences in $R_{15}$ between the different levels along the stem were smaller than on a volume base. There was less consistency in the variation of $R_{15}$ and $R_{\mathrm{M} 15}$ along the stem in 1997 and 1998 than on a volume base (figure $2 b$ ) since the respiration rate did not necessarily increase with height or decrease with diameter. Therefore, maintenance respiration is more difficult to predict on a surface area base. At breast height, the factor of variation between the trees was 39\% higher when respiration was calculated on a surface base than when it was calculated on a volume base.

\section{4. $Q_{10}$ calculations}

As a rule, $Q_{10}$ tended to increase with the number of days used to calculate it. In 1998, on a one-day, three-day and seven-day calculation base, the averaged $Q_{10}$ was 1.29 ( $S E=$ $0.06), 1.33(S E=0.05)$ and $1.35(S E=0.06)$, respectively, for cuvettes installed at breast height. $Q_{10}$ can be underestimated when calculated with a short time-step and calculations over a long period can also induce problems, if calculations are applied to different physiological status of the wood. A three-day period was found to be a good compromise. When calculated with day-time values only, but for a three days

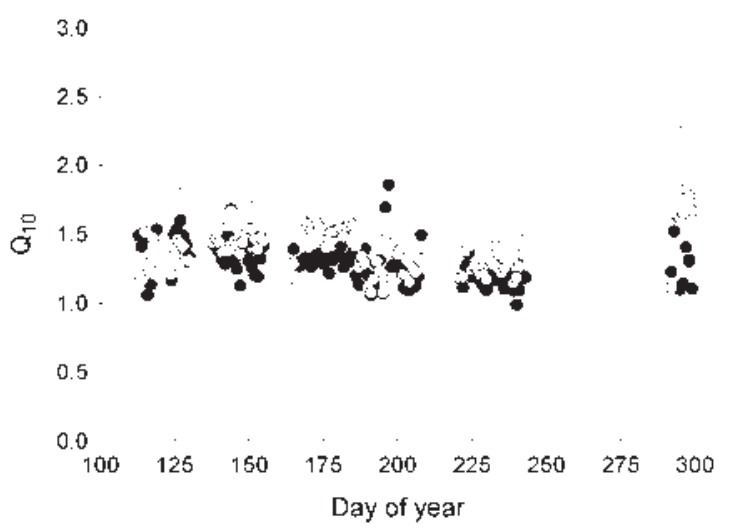

Figure 3. Seasonal variation in averaged $Q_{10}$ of dominant or co-dominant 25-year-old beech trees at Hesse in 1998: at breast height ( three to four cuvettes per point) and at mid-stem $(\bigcirc$, three cuvettes per point). The error bars represent the maximum standard errors for both locations.

period, $Q_{10}$ was 1.43 instead of 1.33 . The hysteresis commonly observed when respiration is plotted against temperature tends to overestimate $Q_{10}$ when it is calculated on a diurnal base only. Introduction of a time-lag correction into the calculations increased the estimate of $Q_{10}$. However, as the time-lag between respiration and temperature varied inconsistently from 0 to 12 hours, and because this lag was not predictable, our $Q_{10}$ estimates are presented without a correction for time-lag. There was no significant temperature-dependence of the $Q_{10}$ at the top of the trees since the slope of the linear relationship between $Q_{10}$ and stem temperature was very small and not significant (data not shown).

Through the season, $Q_{10}$ values ranged from 1.0 to 1.85 at breast height and from 1.08 to 2.25 at mid-stem. No clear seasonal variations were observed and most of the time $Q_{10}$ was higher at mid-stem than at breast height (figure 3). The annual averaged $Q_{10}$ from 1998 and 1997 for each position shows that $Q_{10}$ increased with height or decreased with increasing diameter (table I). The diameters, heights, peaks of respiration rates, estimated at $15{ }^{\circ} \mathrm{C}$, and maintenance respiration rates estimated at $15{ }^{\circ} \mathrm{C}$, for the different cuvette positions in 1997 and 1998 are also given in table I.

\subsection{The growth and maintenance components of stem respiration}

Method 1: The relationships between total growth respiration and the amount of wood produced in six cuvettes during 1998 and in the mid-crown cuvette during 1997, are shown in figure 4 . The linear relationship $\left(r^{2}=0.89, n=7\right)$ shows that the growth respiration coefficient was rather constant along the stem. For $1 \mathrm{~g}$ of carbon fixed in the new tissue, $0.23 \mathrm{~g}$ of carbon was respired. 


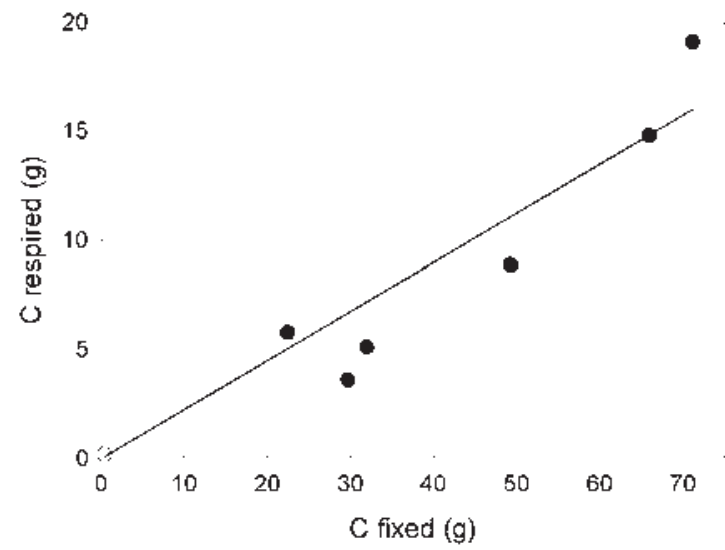

Figure 4. Relationship obtained by Method 1 between carbon fixed in the newly-formed tissue and carbon respired by growth respiration in the lower and middle cuvettes in 1998 (O) and the middle cuvette in the crown in $1997(\bigcirc)$. One cuvette per point; the solid line represents the regression $Y=0.23 \times X$ (the intercept was set to 0$), r^{2}=0.89$.

The use of the mature-tissue method indicated that in $1998,66.6 \%(S E=1.3)$ of total stem respiration at breast height was growth respiration, compared with $44.6 \%$ ( $S E=$ 4.5 ) at mid-stem (table II), in spite of a higher annual relative diameter growth than at breast height $(8.1 \%, S E=0.5$ and $3.1 \%, S E=0.2$, respectively). The relative growth for the upper stem was ca. $33.5 \%(S E=3.8)$ in 1998. On average for 1997 and 1998, the percentage of total respiration represented by growth respiration $\left(R_{\mathrm{G}} \%\right)$ was $56.5 \%(S E=4.8)$.

Method 2: The use of the periodic-growth method indicated that on average for $1 \mathrm{~g}$ of carbon fixed in new tissues, $0.20 \mathrm{~g}(S E=0.04)$ of carbon was respired (figure 5). The $r^{2}$ of the relationship between carbon fixed and carbon respired by growth respiration, ranged between 0.57 and $0.85(P=0.05)$. Growth respiration was estimated to be on average $64.9 \%$ $(S E=7.8)$ of the total annual respiration in the cuvettes (table II).

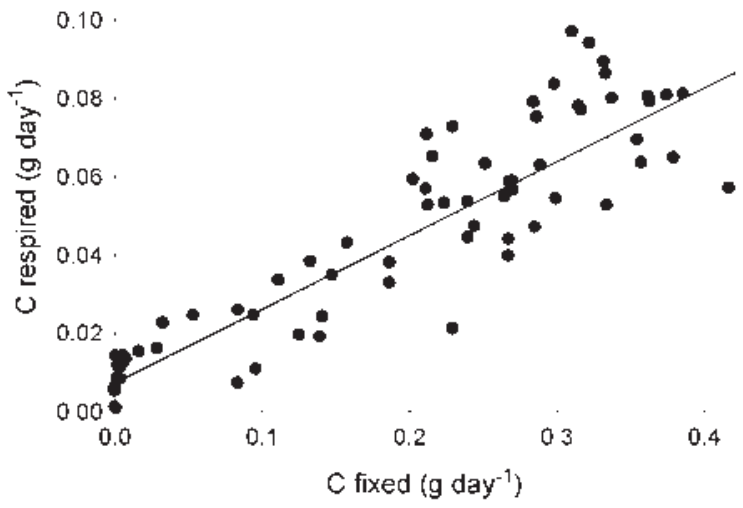

Figure 5. Relationship obtained by Method 2 between carbon fixed in the newly-formed tissue and carbon respired by growth respiration in one of the middle cuvettes in 1998. The solid line represents the regression $Y=0.19 \times X+0.008, r^{2}=0.85$.

Both methods gave on average similar estimates of the growth respiration coefficient, but the contribution of growth respiration to total respiration differed. For Method 2 the averages were calculated on mid-stem and breast height cuvettes, whereas the averages for $r_{\mathrm{G}}$ and $R_{\mathrm{G}} \%$, respectively, were 0.13 and $53.9 \%$ at breast height and 0.27 and $75.9 \%$ at mid-stem. Both $r_{\mathrm{G}}$ and $R_{\mathrm{G}} \%$ had higher values at mid-stem than at breast height according to Method 2, but the difference was significant for $r_{\mathrm{G}}$ only $(t$-test, $P=0.019)$.

\subsection{Live cells and nitrogen analysis}

In the xylem, all of the living cells were found in the rays and down to the centre of the stem. The percentage of living cells was rather stable in the xylem from the surface to the centre of the stem (mean $=20.6, S E=0.43$ ). The total percentage of living cells at breast height was very close to the

Table II. Spatial variation in total annual respiration $\left(R_{\mathrm{T}}\right)$ and wood production in each cuvette and comparison between Methods 1 and 2 for the percentage that represents growth respiration $\left(R_{\mathrm{G}} \%\right)$ in $R_{\mathrm{T}}$ and comparison of the growth respiration coefficient $\left(r_{\mathrm{G}}\right)$. The $r^{2}$ of the relationship between $\mathrm{C}$ respired and $\mathrm{C}$ fixed for Method 2 is also presented for each cuvette. Values in parenthesis are standard errors of the means.

\begin{tabular}{|c|c|c|c|c|c|c|c|}
\hline \multirow[t]{2}{*}{ Cuvette positions } & \multirow{2}{*}{$\begin{array}{l}\text { Wood production } \\
\left(10^{3} \mathrm{~mm}^{3}\right)\end{array}$} & \multirow[t]{2}{*}{$R_{\mathrm{T}}(\mathrm{mol})$} & \multicolumn{2}{|c|}{ Method 1} & \multicolumn{3}{|c|}{ Method 2} \\
\hline & & & $r_{\mathrm{G}}$ & $R_{\mathrm{G}} \%$ & $r_{\mathrm{G}}$ & $r^{2}$ & $R_{\mathrm{G}} \%$ \\
\hline Breast height 1 & 207 & 644 & \multirow{7}{*}{0.23} & 66.7 & 0.12 & 0.70 & 64.8 \\
\hline Breast height 4 & 224 & 691 & & 63.9 & 0.10 & 0.85 & 33.8 \\
\hline Mean Breast height & $195(21)$ & $591(63)$ & & $66.6(1.3)$ & $0.13(0.02)$ & $0.74(0.05)$ & $53.9(10.1)$ \\
\hline Mid-stem 1 & 164 & 128 & & 33.7 & 0.31 & 0.67 & 92.8 \\
\hline Mid-stem 3 & 101 & 146 & & 49.1 & 0.19 & 0.85 & 62.1 \\
\hline Mean Mid-stem & $112(48)$ & $154(15)$ & & $44.6(4.5)$ & $0.27(0.04)$ & $0.69(0.07)$ & $75.9(9.0)$ \\
\hline Mid-crown & 1.4 & 4 & & 61.9 & - & - & - \\
\hline
\end{tabular}


total percentage of living cells in the xylem (figures $6 a$ and $6 b$ ), which demonstrates that the number of living cells in the periderm is negligible in this location. The integration of the sections at several depths over the entire stem section showed that the mean percentage of living cells was close to $20.6 \%$ $(S E=0.88)$, but decreased with DBH (figure 6b).

In the crown, the percentage of living cells in the xylem decreased strongly with increase of stem diameter (figure $6 a$ ), from $48 \%$ to $21 \%$ at $1.8 \mathrm{~mm}$ and $8.2 \mathrm{~mm}$ diameter, respectively. The total percentage of living cells also decreased with increase of stem diameter, from $60.3 \%$ to $32.7 \%$ for stem diameters of 2.2 and $11 \mathrm{~mm}$, respectively (figure $6 b$ ). Moreover, the proportion of xylem tissue compared to the other tissues strongly increased with stem diameter (figure 7). Pith thickness was constant and the percentage of living cells in the pith was on average $45 \%$ lower than the

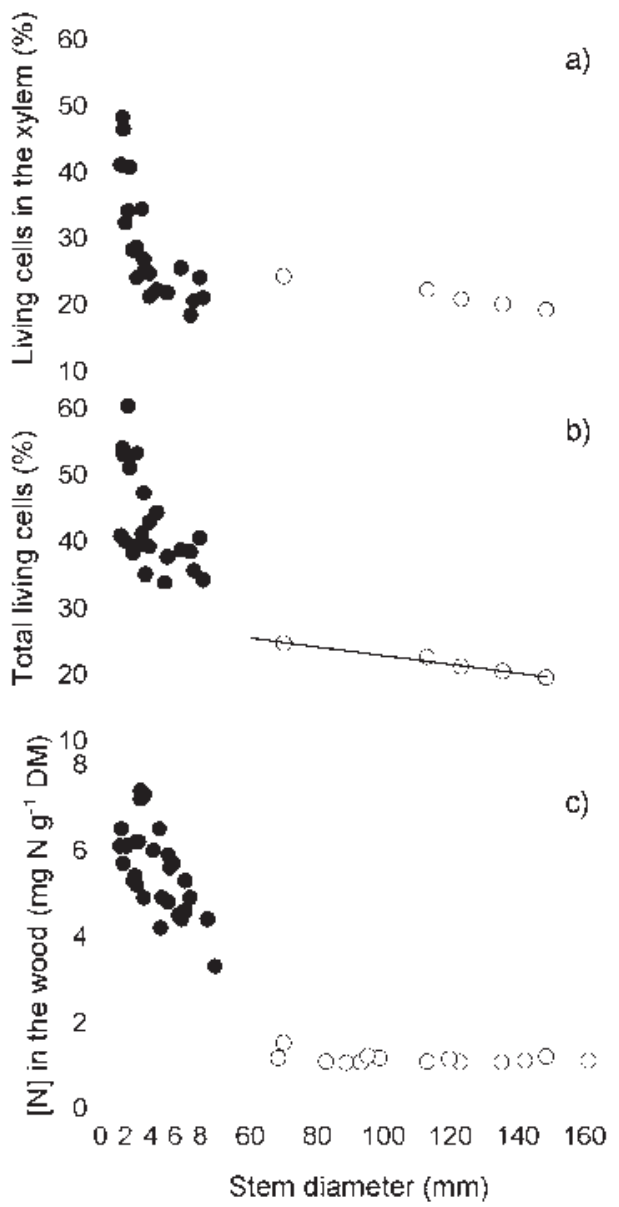

Figure 6. Percentage of living cells in the xylem (a), over the entire section (b) and nitrogen concentration in the wood (c) as a function of stem diameter for 25-year-old beech trees at Hesse in 1998; in the crown $(\bigcirc)$ and at breast height $(\bigcirc)$. The solid line represents the regression for the breast height samples, $Y=-0.066 \times X+24.5$, $r^{2}=0.97$. percentage of living cells in the xylem at the same diameter (data not shown). The percentage of living cells in the periderm was rather constant, averaging $55.6 \%(S E=0.90)$.

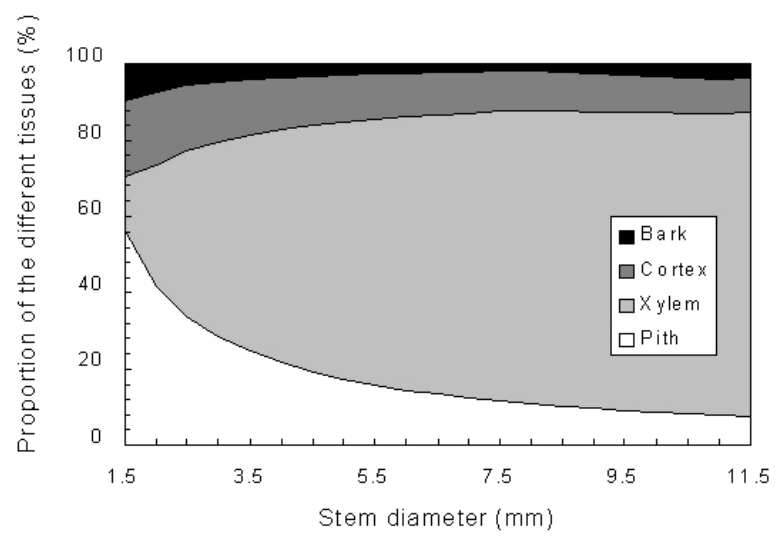

Figure 7. Representation of the relative proportion of different tissues in the stem within the crown, as a function of their diameter for 25-year-old beech trees at Hesse in 1998.

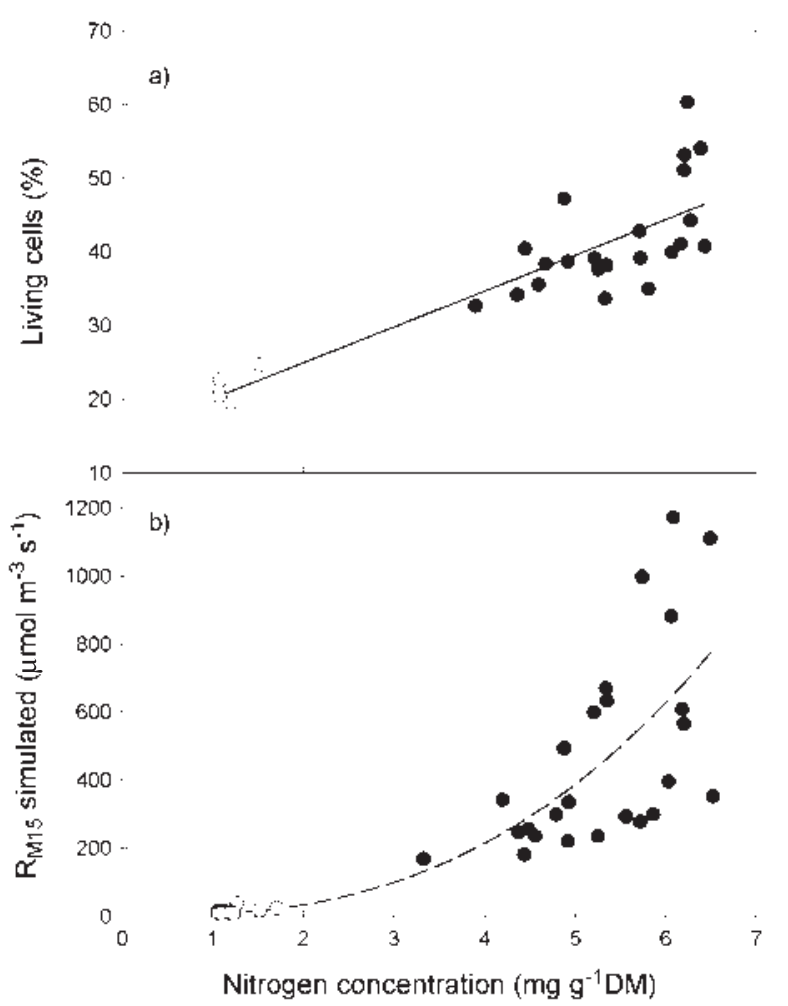

Figure 8. Percentage of living cells in the stem and simulated $R_{\mathrm{M} 15}$ as a function of nitrogen concentration in the stem in the crown $(\mathbf{O})$ and at breast height $(O)$ for 25 -year-old beech trees at Hesse in 1998. The solid line represents the regression for the percentage of living cells $\left(Y=4.86 \times X+15.3, r^{2}=0.74\right)$. The dashed line represents the regression for the simulated $R_{\mathrm{M} 15}\left(Y=-88.9+62.0 \times \mathrm{e}^{(0.41 \times X)}, r^{2}=0.68\right)$. 
Corresponding to the decrease in living cells, the nitrogen concentration decreased strongly with stem diameter in the crown, from $7.5 \mathrm{mg} \mathrm{N} \mathrm{g}^{-1} \mathrm{DM}$ to $3.3 \mathrm{mg} \mathrm{N} \mathrm{g}^{-1} \mathrm{DM}$ for organs with diameters close to 2 and $9 \mathrm{~mm}$, respectively (figure $6 \mathrm{c}$ ). At breast height, there were very little changes in $[\mathrm{N}]$ with changes in stem diameter and nitrogen concentration was close to $1 \mathrm{mg} \mathrm{N} \mathrm{g}^{-1}$. There was a linear relationship between the total percentage of living cells in the stem and $[\mathrm{N}](Y=$ $4.86 \times[\mathrm{N}]+15.3, n=20$ and $\left.r^{2}=0.74\right)$, but the relationship between simulated respiration (calculated from the relationship shown in figure $2 a$ ) on a volume base and nitrogen concentration was not linear (figure 8). The model $Y=-88.9+$ $62.0 \times \mathrm{e}^{(0.41 \times[\mathrm{N}])}$ was the best fit to the respiration data $(n=41$ and $r^{2}=0.68$ ), suggesting that respiration increases non-linearly with the volume of living cells.

\section{DISCUSSION}

\subsection{Seasonal variations in respiration}

Total stem respiration varied throughout the year with maximum rates during summer and minimum rates during winter. These variations, corrected to $15^{\circ} \mathrm{C}$, were related to variations in diameter increment, but were not synchronised. The time-lag between respiration and growth was not constant, which implies that daily measurements are needed to match the changes in growth and respiration through the season. This is necessary for estimating the growth respiration coefficient by the periodic-growth method. In Stockfors and Linder [46], it was noted that the lag between growth and respiration peaks varied between 10 and 20 days for Picea abies. A possible explanation for this phenomenon is the lag between diameter growth and increase in dry matter caused by a delay in wall thickening and lignification [50]. Surprisingly, respiration at mid-stem and breast height was not synchronised, whereas growth was. The lag between growth and respiration was greater at breast height, perhaps because more wall thickening is needed at breast height to support the entire structure of the tree. A second hypothesis is that allocation of assimilates translocated from the leaves in the crown went as a first priority to closer woody organs for wall thickening.

\subsection{Spatial variations in respiration}

In accordance to previous studies [28, 32, 40, 41, 49], stem respiration varied strongly within a tree in Hesse. The factor of variation for respiration was higher when calculated on a volume base than on a surface-area base. The stem respiration rates measured at breast height were similar to those reported in similar studies for conifers $[21,38]$ and broadleaved trees $[10,15,16]$. Our measurements in the crown showed respiration rates higher than those in Möller et al. [32] on beech trees, but Yoda et al. [49] on broadleaved trees found maintenance respiration rates similar to those in our study.
On a surface-area base, our measurements in the crown are also similar to those reported on conifers $[28,40]$.

A principal factor responsible for the spatial variation of woody total respiration was the difference in temperature between the organs. Considering $R_{\mathrm{M} 15}$ and $Q_{10}$ values at breast height and for the upper stem location, the differences in temperature would explain at most $68.5 \%$ of the spatial variation in measured respiration rates during the non growing period. Stockfors [45] showed that failure to consider temperature differences within the stem could produce errors representing about $58 \%$ of total annual stem respiration.

Even after total respiration was corrected for temperature differences, respiration calculated on a volume base at the top of the tree was greater than that at breast height. This is partly caused by the higher relative growth of the stem in its upper parts during the growing season. The measurements of spatial variability in $R_{\mathrm{M} 15}$ during the non-growing periods showed that $R_{\mathrm{M}}$ also increased with height along the stem. The main reasons are that periderm had a higher percentage of living cells than other tissues and that the proportion of the periderm compared to the other tissues decreased when the diameter of the organ increased. Moreover, the proportion of living cells in the xylem and in the pith also decreased with increasing diameter. In consequence, the total amount of cells per unit surface or volume of stem decreased with increasing diameter, corresponding to a decrease in the maintenance respiration rate. Since larger diameters usually corresponded to older stems, our observations are globally in agreement with Carey et al. [6], who showed that $R_{\mathrm{M}}$ decreased with DBH and age.

The percentage of living cells in the organs was much higher for beech than for most of the other species studied. At breast height, the percentage of living cells in the sapwood was $5.0 \%$ for Pinus contorta, 5.7\% for Picea engelmanii [36] and only $0.1-0.5 \%$ for Picea abies [46] compared with about $22 \%$ for beech. Such a difference is explained by the much bigger size and number or rays for beech compared to the conifers mentioned above. This is confirmed by our own observations of the living tissues in Picea abies [7].

The distribution of the living cells in the stem was also quite different from that found for Picea abies [7, 46]. In Picea abies, $80 \%$ of the living cells were situated in the first $4 \mathrm{~mm}$ beneath the bark at breast height, and the percentage of live cells decreased towards the centre of the stem [46]. For Pinus contorta and Picea engelmanii more than $80 \%$ of the living cells were also situated in the sapwood [36]. The difference in distribution of the living cells within the stem in different species could explain why some authors have found that respiration was better correlated with wood surface [46] or with volume [36]. For the beech trees we studied, volume seems to be the most appropriate base for calculation of stem maintenance respiration rates since an important proportion of the living cells are situated in the xylem. 
As in our study, Bosc [5] found that in maritime pine (Pinus pinaster Ait.), maintenance respiration increases strongly with $[\mathrm{N}]$. For beech, maintenance respiration increased according to an exponential relationship with [N]. Since the relationship between $[\mathrm{N}]$ and the percentage of living cells was linear for beech, respiration also increased in an exponential relationship with the percentage of living cells. For the smaller and younger organs, respiration increased strongly, indicating that the living cells in these young organs are probably more physiologically active than those in the older ones. Bosc [5] showed that the combined effect of age and tissue vitality could explain part of the differences in maintenance respiration rates within the tree.

Nevertheless, branches and stems in the crown have a much higher respiration rate on a volume or mass base than does the stem at breast height $[32,49]$. This fact is critical, since the proportion of organs in the crown (stem and branches) compared to the total amount of wood is large in beech trees (11\% in volume and 53\% in area in [8]). Further investigations concerning the variation in respiration rates within the crown, especially for branches in the lower part of the canopy, would be needed in order to assess the relationships between $R_{\mathrm{M}}$, diameter and age of the organs.

\subsection{Estimation of $Q_{10}$}

Our value of $Q_{10}$ without correction for the time-lag at breast height $\left(Q_{10}=1.33\right.$ on average $)$ is low compared with most other values found in the literature, even if Lavigne and Ryan [20] found $Q_{10}$ values between 1.0 and 1.7 for old aspen trees. Other studies report $Q_{10}$ values of 1.2 to 3 for Pinus banksiana [19], 1.5 to 3.2 for Chamaecyparis obtusa [34] and 1.9 to 2.6 for Picea abies [46].

$Q_{10}$ also varied within the trees, from 1.18 at breast height to 2.25 in the crown. The response of respiration to changes in temperature was faster for smaller-diameter organs. The thicker bark and periderm could slow down the diffusion of $\mathrm{CO}_{2}$ through the stem and partly be responsible for this observation [13]. However, the slower response of respiration to changes in temperature measured $2 \mathrm{~mm}$ under the bark, is also probably caused by the delay in warming of the internal parts of the stem compared to the superficial parts. Stockfors [45] and Derby and Gates [9] have observed gradients in temperature within the stem, of up to $21^{\circ} \mathrm{C}$. The greater the diameter, the longer it will take to reach a homogeneous temperature, and in consequence, the time-lag between changes in temperature and changes in respiration increases with the diameter of the stem $[5,21]$.

In contrast to some other studies [27, 47], no $Q_{10}$ temperature-dependence was found and no clear seasonal pattern in $Q_{10}$ was observed. Stockfors and Linder [46] for Picea abies and Paembonan et al. [34] for Chamaecyparis obtusa, observed a clear seasonal variation of $Q_{10}$, but Linder and Troeng [24, 25] did not find such variations in Pinus sylvestris.

\subsection{Separation of the total respiration into its components}

Continuous respiration measurements improve the accuracy of the estimated components of stem respiration, since respiration rates vary relatively fast. However, both methods used to separate total respiration into its components lead to rather similar results concerning the growth respiration coefficient $\left(r_{\mathrm{G}}=0.23\right.$ by Method 1 and 0.20 by Method 2$)$, but not for the percentage of growth respiration over total respiration (56.5\% by Method 1 and 64.9 by Method 2). These percentages are similar to those found by Ryan [36] and Stockfors and Linder [46] in conifers $\left(R_{\mathrm{G}} \%\right.$ ranged between 40 and $60 \%$ of the total annual respiration). $R_{\mathrm{G}} \%$ was, however, higher at mid-stem than at breast height by Method 2 (75.9\% and $53.9 \%$ respectively), but lower by Method 1 (44.6 and 66.6\% respectively).

Our mean values of $r_{\mathrm{G}}$ are rather consistent with similar studies and are close to the theoretical value of 0.25 found by Penning de Vries [35], but the $r_{\mathrm{G}}$ values obtained at breast height by Method 2 are among the smallest reported. Lavigne and Ryan [20] estimated that the growth respiration coefficient in Pinus banksiana and Picea mariana was between 0.24 and 0.39 and Wullschleger et al. [48] estimated $r_{\mathrm{G}}$ to be 0.21 to 0.25 for Quercus alba saplings. Stockfors and Linder [46] found $r_{\mathrm{G}}$ values between 0.11 and 0.2 , depending on the methods used, but with the lower values for the mature-tissue method. They suggested that the use of the mature-tissue method can pose problems, since $R_{\mathrm{M}}$ is assumed to be constant through the year, whereas some studies have shown that $R_{\mathrm{M}}$ can acclimate to changes in temperature [25,34] or varies with [N] in the wood [28]. Moreover, similar regressions as those obtained by Method 2 were made by using total respiration instead of growth respiration (which is the result of the subtraction of maintenance respiration from total respiration) and the slopes were similar to those obtained by Method 2 . This result indicates that Method 2 is not sensitive to errors in estimates of maintenance respiration.

\section{CONCLUSION}

Annual growth respiration accounted for about $60 \%$ of total respiration with a growth respiration coefficient close to 0.2 . The distribution of the living cells in the stem tends to show that for young beech trees, volume is a better base for calculating stem maintenance respiration than is surface area.

Respiration rates varied within the tree by a factor up to 68 -fold when calculated on a volume base. Most forest carbon-cycle models that estimate stem respiration at stand level assume that respiration rates, temperature and $Q_{10}$ are constant within the tree. Such assumptions can induce large errors of estimation for woody respiration at the tree and stand level, if those parameters vary within the tree, as in our study. More information is also needed concerning variations in 
branch respiration rates and bark $\mathrm{CO}_{2}$ refixation, in order to improve the stand-level calculations for respiration of woody organs.

Acknowledgments: We thank people from the INRA team of Nancy who provided assistance on the field and gave us information and data on the Hesse site. We are also grateful to B. Saugier, J.G.K. Flower-Ellis and S. Linder for critically reading this manuscript. This study was supported by the European programme Euroflux (ENV4-CT95-0078) coordinated by R. Valentini, the French National Forest Service (ONF), and a multidisciplinary programme on interactions between Man and Environment of CNRS: "Environnement, Vie et Sociétés".

\section{REFERENCES}

[1] Amthor J.S., The role of maintenance respiration in plant growth, Plant Cell Environ. 7 (1984) 561-569.

[2] Amthor J.S., Respiration and Crop Productivity, Springer-Verlag, New York, 1989, 215 p.

[3] Anttonen S., Manninen A.-M., Saranpää P., Kainulainen P., Lundmark T., Linder S., Vapaavuori E., Long-term nutrient optimisation affects the chemical composition of Norway spruce stem wood, in: Radoglou K. (Ed.), Forest Research: A Challenge for an Integrated European Approach, Volume II, 2001, pp. 643-648.

[4] Benecke U., Nordmeyer A.H., Carbon uptake and allocation by Nothofagus solandri var. cliffortioides (Hook. f.) Poole and Pinus contorta Douglas ex Loudon ssp. contorta at montane and subalpine altitudes, in: Waring R.H. (Ed.), Carbon Uptake and Allocation in Subalpine Ecosystems as a Key to Management, Forest Res. Lab., Oregon State Univ., Corvallis, OR, 1982, pp. 9-21.

[5] Bosc A., Étude expérimentale du fonctionnement hydrique et carboné des organes aériens du Pin maritime (Pinus pinaster Ait.) : intégration dans un modèle Structure-Fonction appliqué à l'analyse de l'autonomie carbonée des branches de la couronne d'un arbre adulte. Thesis of Université Victor Segalen Bordeaux 2, 1999, $225 \mathrm{p}$.

[6] Carey E.V., Callaway R.M., DeLucia E.H., Stem respiration of ponderosa pines grown in contrasting climates: implications for global climate change, Oecologia 111 (1997) 19-25.

[7] Ceschia É., Environmental effects on spatial and seasonal variations of stem respiration in European beech and Norway spruce. Acta Universitatis Agriculturae Sueciae (Silvestria) 219, 2001, 56 p.

[8] Damesin C., Ceschia É., Le Goff N., Ottorini J.-M., Dufrêne É., Stem and branch respiration of beech: from tree measurements to estimations at the stand level, New Phytol. 153 (2002) 159-172.

[9] Derby R.W., Gates D.M., The temperature of tree trunks-calculated and observed, Amer. J. Bot. 53 (1966) 580-587.

[10] Edwards N.T., Hanson P.J., Stem respiration in a closed-canopy upland oak forest, Tree Physiol. 16 (1996) 433-439.

[11] Edwards N.T., Wullschleger S.D., Carbon dioxide efflux rates from stems of mature Quercus prinus L. and Acer rubrum L. trees do not appear to be affected by sapflow rates, J. Sustainable Forestry 10 (2000) 125-131.

[12] Eklund L., Endogenous levels of oxygen, carbon dioxide and ethylene in stems of Norway spruce trees during one growing season, Trees 4 (1990) 150-154.

[13] Eklund L., Lavigne M.B., Restricted lateral gas movement in Pinus strobus branches, Trees 10 (1995) 83-85.

[14] Granier A., Ceschia É., Damesin C., Dufrêne É., Epron D., Gross P., Lebaube S., Le Dantec V., Le Goff N., Lemoine D., Lucot É., Ottorini J.-M., Pontailler J.-Y., Saugier B., The carbon balance of a young beech forest, Funct. Ecol. 14 (2000) 312-325.
[15] Kakubari Y., Diurnal and seasonal fluctuations in the bark respiration of standing Fagus sylvatica trees at Solling, West Germany, J. Jpn. For. Soc. 70 (1988) 64-70.

[16] Kakubari Y., Diurnal and seasonal fluctuations in the bark respiration of standing Quercus acutissima trees in Nakaizu, in: Dreyer E., Aussenac G., Dizengremel P., Favre J.-M., Garrec J.P., Le Tacon F., Martin F. (Eds.), Forest Tree Physiology, Elsevier/INRA 46 suppl., 1989, pp. 529-531.

[17] Kirsten W.J., Hesselius G.U., Rapid, automatic, high capacity Dumas determination of nitrogen, Microchem. J. 28 (1983) 529-547.

[18] Lavigne M.B., Stem growth and respiration of young balsam fir trees in thinned and unthinned stands, Can. J. For. Res. 18 (1988) 483-489.

[19] Lavigne M.B., Comparing stem respiration and growth of jack pine provenances from northern and southern locations, Tree Physiol. 16 (1996) $847-852$.

[20] Lavigne M.B., Ryan M.G., Growth and maintenance respiration rates of aspen, black spruce, and jack pine stems at northern and southern BOREAS sites, Tree Physiol. 17 (1997) 543-551.

[21] Lavigne M.B., Franklin S.E., Hunt E.R. Jr, Estimating stem maintenance respiration rates of dissimilar balsam fir stands, Tree Physiol. 16 (1996) 687-695.

[22] Lebaube S., Le Goff N., Ottorini J.-M., Granier A., Carbon balance and tree growth in a Fagus sylvatica stand, Ann. For. Sci. 5 (2000) 49-61.

[23] Levy P.E., Meir P., Allen S.J., Jarvis P.G., The effect of aqueous transport of $\mathrm{CO}_{2}$ in xylem sap on gas exchange in woody plants, Tree Physiol. 19 (1999) 53-58.

[24] Linder S., Troeng É., Photosynthesis and transpiration of 20-year-old Scots pine, Ecol. Bull. (Stockholm) 32 (1980) 165-181.

[25] Linder S., Troeng É., The seasonal variation in stem and coarse root respiration of a 20-year-old Scots Pine, Mitt. Forstl. Bundes-Versuchsanst. Wien 142 (1981) 125-139.

[26] Lindroth A., Grelle A., Móren A.-S., Long term measurements of boreal forest carbon balance reveal large temperature sensitivity, Global Change Biology 4 (1998) 443-450.

[27] Lloyd J., Taylor A., On the temperature dependence of soil respiration, Funct. Ecol. 8 (1994) 315-323.

[28] Maier C.A., Zarnoch S.J., Dougherty P.M., Effects of temperature and tissue nitrogen on dormant season stem and branch maintenance respiration in a young loblolly pine (Pinus taeda) plantation, Tree Physiol. 18 (1998) $11-20$.

[29] Malkina I.S., Yakshina A.M., Tsel'niker Yu.L., Relationship between $\mathrm{CO}_{2}$ evolution by the trunk and gas-exchange of the leaves in oak, Sov. Plant Physiol. 32 (1985) 593-599.

[30] Martin T.A., Teskey R.O., Dougherty P.M., Movement of respiratory $\mathrm{CO}_{2}$ in stems of loblolly pine (Pinus taeda L.) seedlings, Tree Physiol. 14 (1994) 481-495.

[31] Matthews G., The carbon content of trees. Forestry Commission, Technical Paper 4, Forestry Commission, Edimburgh, 1993, 21 p.

[32] Möller C.M., Müller D., Nielsen J., Respiration in stem and branches of beech. Det Forstlige Forsoegsvaesen i Danmark 21 (1954) 273-301.

[33] Negisi K., Bark respiration rate in stem segments detached from young Pinus densiflora trees in relation to velocity of artificial sap flow, J. Jpn. For. Soc. 61 (1979) 88-93.

[34] Paembonan S.A., Hagihara A., Hozumi K., Long-term measurement of $\mathrm{CO}_{2}$ release from the aboveground parts of a hinoki forest tree in relation to air temperature, Tree Physiol. 8 (1991) 399-405.

[35] Penning de Vries F.W.T., Substrate utilisation and respiration in relation to growth and maintenance in higher plants, Neth. J. Agric. Sci. 22 (1974) $40-44$.

[36] Ryan M.G., Growth and maintenance respiration in stems of Pinus contorta and Picea engelmannii, Can. J. For. Res. 20 (1990) 48-57.

[37] Ryan M.G., The effect of climate change on plant respiration, Ecol. Appl. 1 (1991) 157-167.

[38] Ryan M.G., Linder S., Vose J.M., Hubbard R.M., Dark respiration of pines, Ecol. Bull. (Copenhagen) 43 (1994) 50-63. 
[39] Ryan M.G., Gower S.T., Hubbard R.M., Waring R.H., Gholz H.L., Cropper W.P., Running S.W., Woody tissue maintenance respiration of four conifers in contrasting climates, Oecologia 101 (1995) 133-140.

[40] Ryan M.G., Hubbard R.M., Pongracic S., Raison R.J., McMurtrie R.E., Foliage, fine-root, woody-tissue and stand respiration in Pinus radiata in relation to nitrogen status, Tree Physiol. 16 (1996) 333-343.

[41] Sprugel D.G., Components of woody-tissue respiration in young Abies amabilis (Dougl.) Forbes trees, Trees 4 (1990) 88-98.

[42] Sprugel D.G., Benecke U., Measuring woody-tissue respiration and photosynthesis, in: Lassoie J.P., Hinckley T.M. (Eds.), Methods and approaches in tree ecophysiology, CRC Press, Boca Raton, FL, 1991, pp. 329-355.

[43] Sprugel D.G., Ryan M.G., Brooks J.R., Vogt K.A., Martin T.A., Respiration from the organ level to the stand, in: Smith W.K., Hinckley T.M. (Eds.), Resource Physiology of Conifers: Acquisition, Allocation, and Utilization, Academic Press, New York, 1995, pp. 255-300.

[44] Stockfors J., Respiratory losses in Norway spruce. The effect of growth and nutrition. (Paper III). Acta univ. agricult. suec. (Silvestria) 20, 1997.
[45] Stockfors J., Temperature variations and distribution of living cells within tree stems: implications for stem respiration modelling and scale-up, Tree Physiol. 20 (2000) 1057-1062.

[46] Stockfors J., Linder S., Effect of nitrogen on the seasonal course of growth and maintenance respiration in stems of Norway spruce trees, Tree Physiol. 18 (1998) 155-166.

[47] Tjoelker M.G., Oleksyn J., Reich P.B., Modelling respiration of vegetation: evidence for a general temperature-dependent $Q_{10}$, Global Change Biology 7 (2001) 223-230.

[48] Wullschleger S.D., Norby R.J., Hanson P.J., Growth and maintenance respiration in stems of Quercus alba after four years of $\mathrm{CO}_{2}$ enrichment, Physiol. Plant. 93 (1995) 47-54.

[49] Yoda K., Shinozaki K., Ogawa H., Hozumi K., Kira T., Estimation of the total amount of respiration in woody organs of trees and forest communities, J. Biol. Osaka 16 (1965) 5-26.

[50] M., Annual ring formation on Norway spruce in mountain forest, Med. Nor. Skogførs. Ves. 97 (1969) 165-184. In Norwegian with English summary.

To access this journal online: www.edpsciences.org 